\title{
DUKUNGAN MANAJEMEN PUNCAK SEBAGAI PEMODERASI \\ PENGARUH KAPASITAS SUMBER DAYA MANUSIA DAN TEKNOLOGI INFORMASI PADA IMPLEMENTASI SIPKD DI PEMERINTAH KOTA DENPASAR
}

\author{
Sang Ayu Nyoman Trisna Dewi ${ }^{1}$ \\ I Dewa Nyoman Badera ${ }^{2}$ \\ ${ }^{1,2}$ Fakultas Ekonomi dan Bisnis Universitas Udayana (Unud), Bali, Indonesia \\ e-mail: sangayu.trisnadewi@yahoo.com
}

\begin{abstract}
ABSTRAK
Teknologi informasi telah menjadi bagian utama dalam suatu organisasi. Untuk mewujudkan pemerintahan yang baik, salah satunya dapat dilakukan dengan terus melakukan perbaikan dalam pengelolaan keuangan daerah dan menerapkan aplikasi Sistem Informasi Pengelolaan Keuangan Daerah (SIPKD). Keberhasilan aplikasi ini tidak terlepas dari adanya sumber daya manusia yang berkualitas, teknologi informasi dan dukungan manajemen puncak. Penelitian ini dilakukan dengan menggunakan metode survei dengan teknik kuesioner. Populasi dalam penelitian ini adalah sebanyak 166 responden, terdiri dari pegawai bagian keuangan dan kepala dinas di Pemerintah Kota Denpasar sebanyak 70 responden dengan teknik purposive sampling dan model analisis regresi berganda dan analisis regresi moderasi. Hasil yang diperoleh adalah kapasitas sumber daya manusia dan teknologi informasi berpengaruh positif pada implementasi sistem informasi pengelolaan keuangan daerah. Dukungan manajemen puncak memperkuat pengaruh kapasitas sumber daya manusia dan teknologi informasi pada implementasi SIPKD di Pemerintah Kota Denpasar.
\end{abstract}

Kata Kunci: Kapasitas Sumber Daya Manusia, Teknologi Informasi, Dukungan Manajemen Puncak, dan Implementasi Sistem Informasi Pengelolaan Keuangan Daerah (SIPKD).

\begin{abstract}
Information technology has become a major part of an organization. To realize good governance, one of which can be done by continuing to make improvements in the area of financial management and implement applications Fiscal Management Information System (SIPKD). The success of this application is not separated from the quality of human resources, information technology and management support. This research was conducted using a survey method with questionnaire technique. The population in this research were 166 respondents, consisting of employees of the finance department and agency heads in Denpasar government as much as 70 respondents with a purposive sampling techniques and models of multiple regression analysis and regression analysis moderation. The result is the capacity of human resources and information technology has positive effect on the implementation of financial management information system. Top management support strengthening the influence of human resource capacity and the implementation of information technology in government SIPKD Denpasar.
\end{abstract}

Keywords: Capacity of Human Resources, Information Technology, Top Management Support and Implementation Regional Financial Management Information System (SIPKD). 


\section{PENDAHULUAN}

Teknologi informasi merupakan komponen penting bagi keberhasilan organisasi, tidak terkecuali organisasi disektor pemerintahan. Untuk mewujudkan kinerja pemerintah yang baik, dilakukan upaya dengan menerapkan aplikasi tentang pengelolaan keuangan negara atau daerah. Proses penerapan aplikasi ini membutuhkan suatu sistem informasi keuangan. Sistem informasi merupakan serangkaian prosedur formal dimana data dikumpulkan, diproses menjadi informasi dan didistribusikan ke para pengguna (Cindy and Ros, 2014). Pemerintah Kota Denpasar dalam hal ini telah menerapkan sistem pengelolaan keuangan yang dinamakan Sistem Informasi Pengelolaan Keuangan Daerah (SIPKD) dengan tujuan peningkatan kinerja pegawai dalam mencapai tujuan organisasi sesuai dengan waktu yang telah ditentukan.Kemajuan teknologi informasi mampu meningkatkan kemampuan dalam mengelola Keuangan Daerah, namun terdapat permasalahan dalam penerapan implementasi SIPKD yaitu information asymmetry.

Teori asimetri informasi beranggapan bahwa banyak terjadi kesenjangan informasi antara pihak manajemen dengan pihak masyarakat yang berada di luar manajemen. Fenomena yang terjadi, salah satu pejabat di Perusahaan Daerah Parkir Tahun 2016 terindikasi atas kasus pungutan liar tetapi tetapi belum dikenai hukuman, padahal telah terbukti melakukan pungutan liar (beritabali.com). Hal ini membuktikan bahwa pimpinan tidak memberikan contoh yang baik kepada seluruh bawahannya dan kepada pimpinan lainnya di setiap Satuan Kerja Perangkat Daerah Pemerintah Kota Denpasar. 
Terlepas dari fenomena yang ada, keberhasilan Sistem Informasi Pengelolaan Keuangan Daerah dapat dilihat dari kualitas laporan keuangan di Pemerintah Kota Denpasar yang berhasil mempertahankan opini wajar tanpa pengecualian (WTP) empat kali berturut-turut sejak tahun 2012. Prestasi yang diperoleh Pemerintah Kota Denpasar tersebut tidak lepas dari kualitas sumber daya manusia dan teknologi informasi bagi aparatur di Pemerintah Kota Denpasar.

Faktor-faktor yang mempengaruhi keberhasilan dan kegagalan penerapan sistem informasi antara lain kapasitas sumber daya manusia dan teknologi informasi (Simanjuntak, 2013). Hasil penelitiannya menyatakan bahwa kapasitas sumber daya manusia dan teknologi informasi berpengaruh positif terhadap keberhasilan penerapan sistem informasi. Serupa dengan penelitian Susilatri, Tanjung, dan Pebrina (2010) menunjukkan bahwa keterlibatan pemakai (sumber daya manusia) dan dukungan manajemen puncak berpengaruh positif pada kinerja Sistem Informasi Akuntansi.

Penelitian ini menggunakan kajian teoretis dan kajian empiris. Kajian teoritis dalam penelitian ini terdiri dari grand theory dan supporting theory. Grand theory dalam penelitian ini adalah teori Technology Acceptance Model (TAM) dan teori Motivasi Douglas McGregor. Supporting theory dalam penelitian ini adalah sistem informasi akuntansi, Sistem Informasi Pengelolaan Keuangan Daerah (SIPKD), kapasitas sumber daya manusia, teknologi informasi, dan dukungan manajemen puncak. Kajian empiris dalam penelitian ini berasal dari penelitian yang telah dilakukan oleh peneliti sebelumnya. 
Model TAM adalah teori sistem informasi yang memuat model mengenai sikap individu untuk menerima dan menggunakan teknologi. Teori TAM diadopsi dari Theory of Reasoned Action (TRA), yaitu teori yang menjelaskan bahwa persepsi seseorang terhadap sesuatu akan menentukan sikap dan perilaku orang tersebut. TAM pertama kali diperkenalkan oleh Davis pada tahun 1989. Teori ini menjelaskan bahwa terdapat dua faktor yang memengaruhi perilaku personal untuk menerima dan menggunakan teknologi. Dua faktor tersebut adalah kemudahan penggunaan (ease of use) dan kebermanfaatan (usefulness) (Surendran, 2012).

1) Persepsi Kemudahan Penggunaan (Ease of Use Perceived)

Dalam Davis (1989) disebutkan bahwa "ease"artinya "freedom from difficulty or great effort". Selanjutnya "ease to use perceived" didefinisikan"the degree to which a person believes that using a particularrsystem would be free of effort”. Jika diaplikasikan untuk Sistem Informasi Pengelolaan Keuangan Daerah Kota Denpasar, maka maksudnya pengguna meyakini kalau Sistem Informasi Pengelolaan Keuangan Daerah Kota Denpasar tersebut mudah dalam penggunaannya sehingga tidak memerlukan usaha keras dan akan terbebas dari kesulitan. Hal ini mencakup kemudahan penggunaan sistem informasi sesuai dengan keinginan penggunanya. Hasil penelitian Davis (1989) menunjukkan jika persepsi kemudahan dapat menjelaskan alasan pengguna untuk menggunakan sistem dan dapat menjelaskan kalau sistem yang baru dapat diterima oleh pengguna. 
2) Persepsi Kebermanfaatan (Usefulness Perceived)

Dalam Davis (1989) disebutkan bahwa"the degree to which a person believes that using a particular system would enhance his or her job performance". Hal ini dimaksudkan bahwa pengguna percaya bahwa dengan menggunakan Sistem Informasi Pengelolaan Keuangan Daerah Kota Denpasar tersebut akan meningkatkan kinerjanya. Hal ini menggambarkan manfaat sistem dari penggunanya yang berkaitan dengan berbagai aspek. Jadi dalam persepsi kebermanfaatan ini membentuk suatu kepercayaan untuk pengambilan keputusan apakah jadi menggunakan sistem informasi atau tidak. Asumsinya jika pengguna mempercayai kalau sistem tersebut berguna maka tentu akan menggunakannya, tetapi sebaliknya jika tidak percaya kalau berguna maka jawabannya pasti tidak akan menggunakannya.

Berdasarkan teori ini, individu dapat memahami manfaat yang diberikan atas penggunaan sistem informasi, sehingga mampu memudahkan individu dalam penggunaannya. Pada penelitian ini, akan dilakukan pengujian mengenai pengaruh dukungan manajemen puncak pada hubungan antara kapasitas sumber daya manusia dan teknologi informasi pada Implementasi Sistem Informasi Pengelolaan Keuangan Daerah (SIPKD).

Teori motivasi yang menggabungkan teori internal dan teori eksternal yang dikembangkan oleh Mc. Gregor. Mc. Gregor telah merumuskan dua perbedaan dasar mengenai perilaku manusia. Kedua teori tersebut disebut teori X dan Y. Teori tradisional mengenai kehidupan organisasi banyak diarahkan dan 
dikendalikan atas dasar teori $\mathrm{X}$. Adapun anggapan yang mendasari teori-teori $\mathrm{X}$ menurut Reksohadiprojo dan Handoko (1996:87):

a. Rata-rata pekerja itu malas, tidak suka bekerja dan kalau bisa akan menghidarinya. Karena pada dasarnya tidak suka bekerja maka harus dipaksa dan dikendalikan, diperlakukan dengan hukuman dan diarahkan untuk pencapaian tujuan organisasi.

b. Rata-rata pekerja lebih senang dibimbing, berusaha menghindari tanggung jawab, mempunyai ambisi kecil, kemamuan dirinya diatas segalanya.

Teori ini masih banyak digunakan oleh organisasi karena para manajer bahwa anggapn-anggapan itu benar dan banyak sifat-sifat yang diamati perilaku manusia, sesuai dengan anggapan tersebut teori ini tidak dapat menjawab seluruh pertanyaan yang terjadi pada organisasi. Oleh karena itu, Mc. Gregor menjawab dengan teori yang berdasarkan pada kenyataannya. Anggapan dasar teori Y adalah:

a. Usaha fisik dan mental yang dilakukan oleh manusia sama halnya bermain atau istirahat.

b. Rata-rata manusia bersedia belajar dalam kondisi yang layak, tidak hanya menerima tetapi mencari tanggung jawab.

c. Ada kemampuan yang besar dalam kecerdikan, kualitas dan daya imajinasi untuk memecahkan masalah-masalah organisasi yang secara luas tersebar pada seluruh pegawai. 
d. Pengendalian dari luar hukuman bukan satu-satunya cara untuk mengarahkan tercapainya tujuan organisasi.

Sistem adalah sekelompok komponen yang saling berkaitan yang terintegrasi untuk bekerja sama dalam mencapai tujuan yang sama. Semua sistem memiliki elemen yang sama (Hall, 2009:6), yaitu:

1) Banyak komponen, sebuah sistem harus berisi lebih dari satu bagian.

2) Berhubungan, tujuan umum dari suatu sistem adalah menghubungkan berbagai bagian dari sistem tersebut. Komponen tersebut dinyatakan bukan bagian dari sistem tersebut, apabila komponen tersebut tidak memberikan kontribusinya pada tujuan bersama.

3) Tujuan, sistem harus mengarah kesatu atau beberapa tujuan. Sistem sebaiknya diganti, apabila sistem tidak lagi mengarah kesebuah tujuan yang sama.

Informasi adalah data yang dikelola dan diproses untuk memberikan arti dan memerbaiki proses pengambilan keputusan. Sebagaimana perannya pengguna membuat keputusan yang lebih baik sebagai kuantitas dan kualitas dari peningkatan informasi (Romney dan Steinbart, 2014:4). Menurut Peraturan Pemerintahan Nomor 71 Tahun 2010, keempat karakteristik berikut ini merupakan prasyarat normatif yang diperlukan agar laporan keuangan pemerintah dapat memenuhi kualitas yang dikehendaki yaitu:

1) Relevan 
Laporan keuangan bisa dikatakan relevan apabila informasi yang termuat di dalamnya dapat mempengaruhi keputusan pengguna dengan membantu mereka mengevaluasi peristiwa masa lalu atau masa kini dan memprediksi masa depan serta menegaskan atau mengoreksi hasil evaluasi mereka di masa lalu. Dengan demikian informasi laporan keuangan yang relevan dapat dihubungkan dengan maksud penggunaannya. Informasi relevan yang dimaksud memiliki kriteria sebagai berikut.

(1) Memiliki manfaat umpan balik (feedback value) Informasi memungkinkan pengguna untuk menegaskan alat mengoreksi ekspektasi mereka di masa lalu.

(2) Memiliki manfaat prediktif (predictive value)

Informasi dapat membantu pengguna untuk memprediksi masa yang akan datang berdasarkan hasil masa lalu dan kejadian masa kini.

(3) Tepat waktu

Informasi disajikan tepat waktu sehingga dapat berpengaruh dan berguna dalam pengambilan keputusan.

(4) Lengkap

Informasi akuntansi keuangan pemerintah disajikan selengkap mungkin yaitu mencakup semua informasi akuntansi yang dapat mempengaruhi pengambilan keputusan. Informasi yang melatarbelakangi setiap butir informasi utama yang termuat 
dalam laporan keuangan diungkapkan dengan jelas agar kekeliruan dalam penggunaan informasi tersebut dapat dicegah.

2) Andal

Informasi Dalam laporan keuangan bebas dari pengertian yang menyesatkan dan kesalahan material, menyajikan setiap fakta secara jujur, serta dapat diverifikasi. Informasi mungkin relevan, tetapi jika hakikat atau penyajiannya tidak dapat diandalkan maka penggunaan informasi tersebut secara potensial dapat menyesatkan. Informasi yang andal memenuhi karakteristik sebagai berikut.

(1) Penyajian Jujur

Informasi menggambarkan dengan jujur transaksi serta peristiwa lainnya yang seharusnya disajikan atau yang secara wajar dapat diharapkan untuk disajikan.

(2) Dapat Diverifikasi (verifiability)

Informasi yang disajikan dalam laporan keuangan dapat diuji, dan apabila pengujian dilakukan lebih dari sekali oleh pihak yang berbeda, hasilnya tetap menunjukkan simpulan yang tidak berbeda jauh.

(3) Netralitas

Informasi diarahkan pada kebutuhan umum dan tidak berpihak pada kebutuhan pihak tertentu.

3) Dapat dibandingkan 
Informasi yang termuat dalam laporan keuangan akan lebih berguna jika dapat dibandingkan dengan laporan keuangan periode sebelumnya atau laporan keuangan entitas pelaporan lain pada umumnya. Perbandingan dapat dilakukan secara internal dan eksternal. Perbandingan secara internal dapat dilakukan bila suatu entitas menerapkan kebijakan akuntansi yang sama dari tahun ke tahun. Perbandingan secara eksternal dapat dilakukan bila entitas yang diperbandingkan menerapkan kebijakan akuntansi yang sama. Apabila entitas pemerintah akan menerapkan kebijakan akuntansi yang lebih baik daripada kebijakan akuntansi yang sekarang diterapkan, perubahan tersebut diungkapkan pada periode terjadinya perubahan.

4) Dapat dipahami.

Informasi yang disajikan dalam laporan keuangan dapat dipahami oleh pengguna dan dinyatakan dalam bentuk serta istilah yang disesuaikan dengan batas pemahaman para pengguna. Untuk itu, pengguna diasumsikan memiliki pengetahuan yang memadai atas kegiatan dan lingkungan operasi entitas pelaporan, serta adanya kemauan pengguna untuk mempelajari informasi yang dimaksud.

Sistem informasi merupakan seperangkat komponen yang saling berhubungan yang berfungsi mengumpulkan, memproses, menyimpan, dan mendistribusikan informasi untuk mendukung pembuatan keputusan dan pengawasan dalam organisasi (Laudon dan Laudon, 2008). Sistem informasi dapat diartikan sebagai suatu rencana data proses dan geografi yang diintegrasikan 
untuk individu yang membentuk suatu kelompok yang dapat digolongkan ke dalam unit-unit organisasi, seperti departemen-departmen, bagian dan kelompok kerja (Bentley and Whitten, 2007).

Sistem Informasi Akuntansi (SIA) merupakan kumpulan sumber daya, seperti manusia dan peralatan, yang dirancang untuk mengubah data keuangan dan data lainnya ke dalam informasi (Bodnar dan Hopwood, 2006). Sistem informasi akuntansi merupakan suatu sistem yang mengumpulkan, mencatat, menyimpan, dan mengolah data untuk menghasilkan informasi bagi pengambilan keputusan (Romney dan Steinbart, 2014:4). Tujuan dasar sistem informasi (Hall, 2009:21).

Sumber daya manusia merupakan elemen organisasi yang sangat penting, oleh karena itu harus dipastikan sumber daya manusia ini harus dikelola sebaik mungkin agar mampu memberi kontribusi secara optimal dalam upaya mencapai tujuan organisasi. Indriasari (2008) mendefinisikan sumber daya manusia sebagai pilar penyangga utama sekaligus penggerak roda organisasi dalam usaha mewujudkan visi dan misi serta tujuan dari organisasi tersebut. Kapasitas sumber daya manusia mencakup kemampuan seseorang atau individu, suatu organisasi (kelembagaan), atau suatu sistem untuk melaksanakan fungsi-fungsi atau kewenangannya untuk mencapai tujuannya secara efektif dan efisien (Azhar, 2007). Kapasitas harus dilihat sebagai kemampuan untuk mencapai kinerja, untuk menghasilkan keluaran (outputs) dan hasil (outcomes).

Tjiptoherijanto (2001) menilai kapasitas dan kompetensi sumber daya manusia dalam melaksanakan suatu fungsi, termasuk akuntansi, dapat 
dilihat dari tingkat tanggung jawab dan kompetensi sumber daya tersebut. Tanggung jawab dapat dilihat dari atau tertuang dalam deskripsi jabatan. Deskripsi jabatan merupakan dasar untuk melaksanakan tugas dengan baik. Tanpa adanya deskripsi jabatan yang jelas, sumber daya tersebut tidak dapat melaksanakan tugasnya dengan baik. Sedangkan kompetensi dapat dilihat dari latar belakang pendidikan, pelatihan- pelatihan yang pernah diikuti, dan dari keterampilan yang dinyatakan dalam pelaksanaan tugas.

Dalam hubungannya dengan sistem informasi akuntansi, komputer akan meningkatkan kapabilitas sistem. Ketika komputer dan komponen-komponen yang berhubungan dengan teknologi informasi diintegrasikan kedalam suatu sistem informasi akuntansi, tidak ada aktivitas umum yang ditambah atau dikurangi. Sistem informasi akuntansi mengumpulkan, memproses dan menyimpan data. Huda (2009) dan Ramezan (2009) menyatakan Teknologi Informasi (TI) adalah istilah umum yang menggambarkan setiap teknologi yang membantu menghasilkan, memanipulasi, menyimpan, berkomunikasi, dan menyebarkan informasi. Ketika berbicara tentang Teknologi Informasi (TI) secara keseluruhan, sering kali dikaitkan dengan penggunaan komputer dan informasi terkait. Supriyanto (2005:5) dan Soegiharto (2001) mengatakan bahwa sebenarnya istilah Teknologi Informasi (TI) atau Information Technologi (IT) yang popular saat ini adalah bagian dari mata rantai panjang dari perkembangan istilah dalam dunia Sistem Informasi (SI) atau Information System (IS). Teknologi Informasi memang lebih mudah dipahami sebagai pengolahan informasi yang berbasis pada teknologi komputer yang saat ini teknologinya terus berkembang sehubungan 
perkembangan teknologi lain yang dapat dikoneksikan dengan komputer itu sendiri. Jogiyanto (2009:18) mengatakan sistem teknologi informasi memberikan lima peran utama dalam organisasi, yaitu meningkatkan efisiensi, efektivitas, komunikasi, kolaborasi dan kompetitif.

Dukungan manajemen puncak adalah pemahaman manajemen puncak terhadap sistem komputer dan tingkat minat, dukungan, dan pengetahuan tentang sistem informasi. Shield (1995) menyatakan bahwa dukungan manajemen puncak (atasan) dalam suatu inovasi sangat penting dikarenakan adanya kekuasaan manajer terkait dengan sumber daya. Delone (1989) dan Choe (1996) dalam Komara (2005) dan Rantanen (2007) telah mengajukan secara empiris menguji bahwa kapabilitas personal dan dukungan manajemen puncak mempunyai pengaruh positif terhadap kinerja sistem informasi akuntansi melalui berbagai macam kegiatan.

Manajer (atasan) dapat fokus terhadap sumber daya yang diperlukan, tujuan dan inisiatif strategi yang direncanakan apabila manajer (atasan) mendukung sepenuhnya dalam implementasi. Manajer adalah seseorang yang bekerja melalui orang lain dengan mengoordinasikan kegiatan-kegiatan mereka guna mencapai sasaran organisasi. Pada organisasi berstruktur tradisional, manajer sering dikelompokan menjadi manajer puncak, manajer tingkat menengah, dan manajer lini pertama (biasanya digambarkan dengan bentuk piramida, di mana jumlah karyawan lebih besar di bagian bawah daripada di puncak). Manejemen lini pertama (first-line management), dikenal pula dengan istilah manajemen operasional, merupakan manajemen tingkatan paling rendah 
yang bertugas memimpin dan mengawasi karyawan non-manajerial yang terlibat dalam proses produksi. Mereka sering disebut penyelia (supervisor), manajer shift, manajer area, manajer kantor, manajer departemen, atau mandor (foreman). Manajemen tingkat menengah (middle management) mencakup semua manajemen yang berada di antara manajer lini pertama dan manajemen puncak dan bertugas sebagai penghubung antara keduanya. Jabatan yang termasuk manajer menengah di antaranya kepala bagian, pemimpin proyek, manajer pabrik, atau manajer divisi. Manajemen puncak (top management), dikenal pula dengan istilah executive officer, bertugas merencanakan kegiatan dan strategi perusahaan secara umum dan mengarahkan jalannya perusahaan.

Penelitian terdahulu berdasarkan penelitian sebelumnya yang terkait dengan penelitian ini yang dilakukan oleh Kim dan Lee (1986) menguji pengaruh antara partisipasi dan kepuasan pemakai dalam pengembangan sistem informasi dengan dukungan manajemen puncak sebagai variabel moderasi. Hasil penelitian menunjukkan dukungan manajemen puncak merupakan variabel moderator. Hasil berbeda diperoleh oleh Yusrawati (2003) yang menguji variabel yang sama, hasil penelitian menunjukkan dukungan manajemen puncak bukan merupakan variabel moderator, namun variabel dukungan manajemen puncak berpengaruh secara langsung terhadap kepuasan pemakai.

Tausikal (2007) menguji pengaruh pemahaman sistem akuntansi dan pengelolaan keuangan daerah terhadap kinerja Satuan Kerja Perangkat Daerah di Kabupaten Maluku Tengah. Hasil penelitian menunjukan secara simultan dan parsial variabel independen berpengaruh terhadap kinerja Satuan Kerja Perangkat 
Daerah. Penelitian yang dilakukan Indriasari (2008) menguji pengaruh kapasitas Sumber Daya Manusia, pemanfaatan Teknologi Informasi dan Sistem Pengendalian Internal terhadap nilai informasi pelaporan keuangan pemerintah daerah, diperoleh hasil pemanfaatan Teknologi Informasi dan Sistem Pengendalian Internal berpengaruh signifikan positif terhadap nilai informasi laporan keuangan pemerintah daerah sedangkan kapasitas Sumber Daya Manusia tidak memiliki pengaruh. Sedangkan penelitian yang dilakukan oleh Dellano (2012) tentang pengaruh kapasitas Sumber Daya Manusia, pemanfaatan Teknologi Informasi, dan pengawasan terhadap nilai informasi pelaporan keuangan pemerintah daerah, diperoleh hasil seluruh variabel berpengaruh signifikan positif terhadap nilai informasi pelaporan keuangan pemerintah daerah.

Penelitian Susilatri, dkk (2010) menyatakan, keterlibatan pemakai dalam proses pengembangan sistem, dukungan manajemen puncak, program pelatihan dan pendidikan pemakai, ukuran organisasi, kemampuan teknik personal sistem informasi, keberadaan dewan pengarah sistem informasi dan lokasi dari departemen sistem informasi berpengaruh positif pada kinerja SIA. Sedangkan formalisasi pengembangan sistem informasi tidak berpengaruh terhadap kinerja Sistem Informasi Akuntansi.

Pada hasil penelitian Komara (2005) dan Almilia dan Briliantine (2007), menunjukkan bahwa keterlibatan pengguna, ukuran organisasi, dukungan manajemen puncak dan formalisasi pengembangan Sistem Informasi berpengaruh positif terhadap kinerja Sistem Informasi Akuntansi. Sedangkan faktor pelatihan dan pendidikan pengguna, komite pengendalian Sistem Informasi dan lokasi 
departemen Sistem Informasi terhadap kepuasan pengguna dan penggunaan sistem informasi tidak berpengaruh terhadap kinerja Sistem Informasi Akuntansi. Sedangkan penelitian Almilia dan Briliantine (2007) menunjukkan hanya dukungan manajemen puncak yang berpengaruh terhadap kepuasan pemakai. Faktor program pelatihandan pendidikan dan keberadaan dewan pengarah datanya tidak dapat diolah. Sedangkan lima faktor lainnya tidak berpengaruh terhadap kepuasan pemakai dan pemakaian sistem

Motivasi peneliti menguji kembali mengenai pengaruh kapasitas sumber daya manusia dan teknologi informasi pada implementasi sistem informasi pengelolaan keuangan daerah, karena terdapat perbedaan hasil penelitianpenelitian sebelumnya. Govindarajan (1986) menyatakan bahwa kemungkinan belum ada kesatuan hasil penelitian atau lebih dikenal dengan istilah faktor kontingensi. Murray (1990) menjelaskan bahwa pendekatan kontingensi dapat digunakan untuk menunjukkaan variabel lain yang dapat menjadi pemoderasi dalam model. Secara konseptual dan hasil riset empiris, variabel yang berperan memoderasi pengaruh kapasitas sumber daya manusia dan teknologi informasi pada implementasi sistem informasi pengelolaan keuangan daerah salah satunya, yaitu dukungan manajemen puncak.

Penggunaan variabel dukungan manajemen puncak sebagai variabel moderasi pernah dilakukan oleh Vanlommel dan DeBrabander (1975) dalam Lau (2004) dan Kim dan Lee (1986) yang menemukan bukti bahwa hubungan antara partisipasi sumber daya dan kepuasan pemakai dipengaruhi oleh dukungan manajemen puncak sebagai variabel moderating. Berdasar uraian diatas, maka 
penelitian ini akan meneliti dukungan manajemen puncak sebagai pemoderasi pengaruh kapasitas sumber daya manusia dan teknologi informasi pada Implementasi Sistem Informasi Pengelolaan Keuangan Daerah (SIPKD) di Pemerintah Kota Denpasar, adapun hipotesis yang diajukan adalah:

$\mathrm{H}_{1}$ : Kapasitas sumber daya manusia berpengaruh pada implementasi SIPKD di Pemerintah Kota Denpasar?

$\mathrm{H}_{2}$ : Teknologi informasi berpengaruh pada implementasi SIPKD di Pemerintah Kota Denpasar?

$\mathrm{H}_{3}$ : Dukungan manajemen puncak memoderasi pengaruh kapasitas sumber daya manusia pada implementasi SIPKD di Pemerintah Kota Denpasar?

$\mathrm{H}_{4}$ : Dukungan manajemen puncak memoderasi pengaruh teknologi informasi pada implementasi SIPKD di Pemerintah Kota Denpasar?

\section{METODE PENELITIAN}

Gambar 1 menunjukkan skema konsep penelitian.

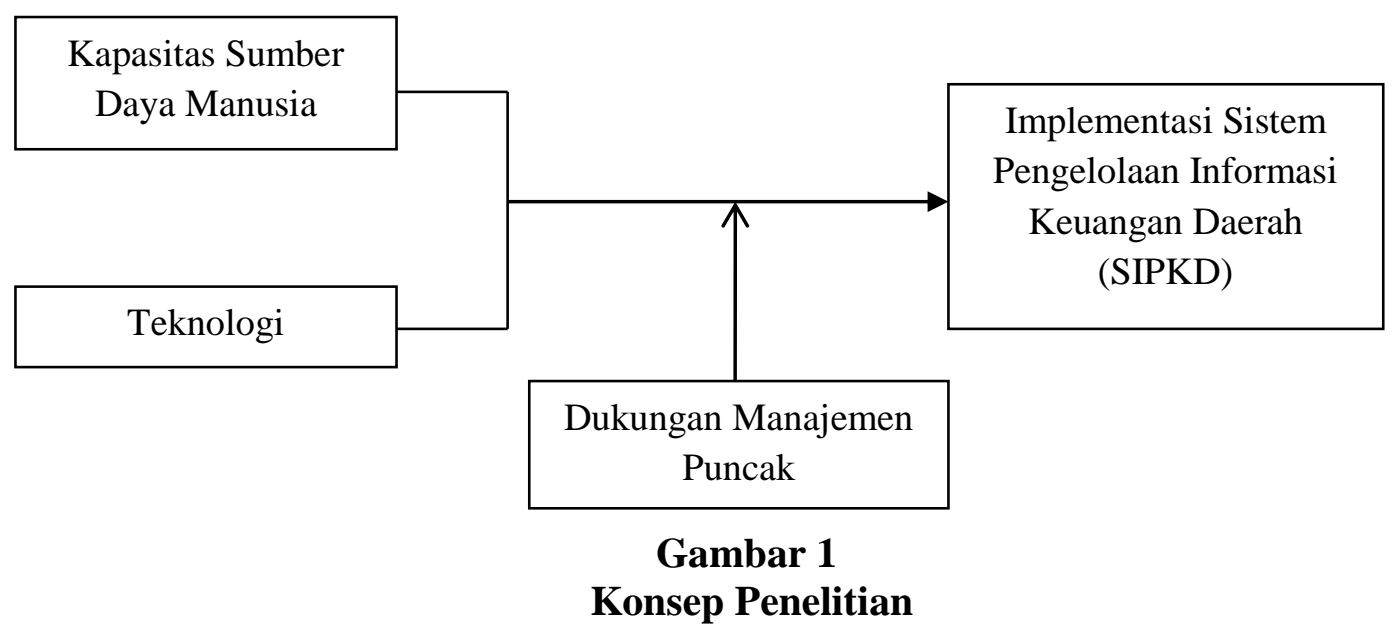


Penelitian ini dilakukan di wilayah kerja Pemerintah Kota Denpasar, yang dilakukan pada Dinas, Badan dan Unit yang termasuk dalam Satuan Kerja Perangkat Daerah pada Sekretariat Daerah Kota Denpasar yang terdiri dari 33 SKPD. Pengumpulan data menggunakan skor total jawaban responden, dengan populasi adalah seluruh pegawai bagian keuangan di SKPD Pemerintah Kota Denpasar dan pemilihan sampel dilakukan dengan teknik purposive sampling. Menurut Susanti (2013:7) kriteria yang digunakan, yaitu: 1) Para pegawai bagian keuangan yang melaksanakan fungsi akuntansi pada Satuan Kerja Perangkat Daerah (SKPD) di Kota Denpasar dan 2) Kepala bagian/dinas akuntansi atau keuangan pada Satuan Kerja Perangkat Daerah (SKPD) di Kota Denpasar.

Analisis moderated regression analysis digunakan dalam model penelitian ini, dengan persamaan regresi moderasi adalah sebagai berikut.

$\hat{Y}=a+\beta_{1} X_{1}+\beta_{2} X_{2}+\beta_{3} X_{3}+\beta_{4} X_{1} X_{3}+\beta_{5} X_{2} X_{3}+\varepsilon$

Keterangan:

$\hat{\mathrm{Y}} \quad=$ Sistem Informasi Pengelolaan Keuangan Daerah (SIPKD)

a $\quad=$ Konstanta

$\beta=$ Koefisien regresi

$\mathrm{X}_{1} \quad=$ Kapasitas Sumber Daya Manusia

$\mathrm{X}_{2} \quad=$ Teknologi Informasi

$\mathrm{X}_{3}=$ Dukungan Manajemen Puncak

$\mathrm{X}_{1} \mathrm{X}_{3}=$ Interaksi Kapasitas Sumber Daya Manusia dengan Dukungan Manajemen Puncak

$\mathrm{X}_{2} \mathrm{X}_{3}=$ Interaksi Teknologi Informasi dengan Dukungan Manajemen Puncak $\varepsilon=$ Error

\section{HASIL PENELITIAN DAN PEMBAHASAN}

Jumlah sampel dalam penelitian ini adalah 70 pegawai. Adapun Tabel 1 menunjukkan sampel penelitian. 
ISSN : 2337-3067

E-Jurnal Ekonomi dan Bisnis Universitas Udayana 6.7 (2017): 2819-2860

Tabel 1

Sampel Penelitian

\begin{tabular}{|c|c|}
\hline Keterangan & Jumlah Orang \\
\hline Jumlah populasi & 166 Orang \\
\hline $\begin{array}{l}\text { Bukan pegawai bagian keuangan yang melaksanakan fungsi } \\
\text { akuntansi atau tata usaha pada SKPD di Kota Denpasar. }\end{array}$ & 82 Orang \\
\hline $\begin{array}{l}\text { 2. Bukan kepala bagian/dinas akuntansi atau keuangan pada } \\
\text { Satuan Kerja Perangkat Daerah (SKPD)di Kota Denpasar. }\end{array}$ & 14 Orang \\
\hline Jumlah sampel yang tidak memenuhi kriteria sampel penelitian & 96 Orang \\
\hline Jumlah sampel penelitian & 70 Orang \\
\hline
\end{tabular}

Ringkasan distribusi kuesioner penelitian disajikan dalam Tabel 2 berikut:

Tabel 2

Tingkat Penyebaran dan Pengembalian Kuesioner

\begin{tabular}{clrc}
\hline No. & \multicolumn{1}{c}{ Keterangan } & Jumlah & \% \\
\hline 1. & Total kuesioner yang disebarkan & 70 & \\
2. & Total kuesioner yang tidak kembali & 0 & \\
3. & Total kuesioner yang kembali & 70 & \multirow{2}{*}{$100 \%$} \\
4. & Response Rate & \multicolumn{2}{c}{} \\
5. & Kuesioner yang tidak dapat digunakan dalam analisis & 0 & \\
6. & Kuesioner yang dapat digunakan dalam analisis & 70 & \\
7. & Useable Response Rate & & $100 \%$ \\
\hline
\end{tabular}

Sumber: data primer diolah (2016)

Tabel 3 menunjukkan hasil uji statistik deskriptif penelitian ini.

Tabel 3.

Uji Statistik Deskriptif

\begin{tabular}{clccccc}
\hline No. & \multicolumn{1}{c}{ Variabel } & N & Min. & Max. & $\begin{array}{c}\text { Rata- } \\
\text { rata }\end{array}$ & $\begin{array}{c}\text { Standar } \\
\text { Deviasi }\end{array}$ \\
\hline 1. & $\begin{array}{l}\text { Kapasitas Sumber Daya Manusia } \\
\left(\mathrm{X}_{1}\right)\end{array}$ & 70 & 18 & 48 & 42,27 & 7,399 \\
2. & Teknologi Informasi $\left(\mathrm{X}_{2}\right)$ & 70 & 19 & 46 & 41,4 & 7,204 \\
3. & Dukungan Manajemen Puncak $\left(\mathrm{X}_{3}\right)$ & 70 & 15 & 35 & 27,29 & 5,251 \\
4. & Implementasi SIPKD (Y) & 70 & 17 & 39 & 33,31 & 5,249 \\
5. & Valid N (listwise) & 70 & & & & \\
\hline
\end{tabular}

Sumber: data primer diolah (2016) 
Tabel 3 memberikan penjelasan:

1) Kapasitas sumber daya manusia $\left(X_{1}\right)$ memiliki nilai minimum 18 dan nilai maksimumnya sebesar 48. Rata-rata kapasitas sumber daya manusia adalah 42,27 dimana artinya rata-rata jawaban responden cenderung mengarah ke nilai tertinggi, dengan standar deviasi adalah 7,399, artinya terjadi penyimpangan nilai kapasitas sumber daya manusia terhadap nilai rata-ratanya sebesar 7,399.

2) Teknologi informasi $\left(X_{2}\right)$ memiliki nilai minimum 19 dan nilai maksimumnya sebesar 46. Rata-rata teknologi informasi adalah 41,40 dimana artinya ratarata jawaban responden cenderung mengarah ke nilai tertinggi, dengan standar deviasi adalah 7,204, artinya terjadi penyimpangan nilai teknologi informasi terhadap nilai rata-ratanya sebesar 7,204.

3) Nilai minimum dari variabel dukungan manajemen puncak $\left(X_{3}\right)$ adalah 15 dan nilai maksimumnya sebesar 35. Rata-rata dukungan manajemen puncak adalah 27,29 dimana artinya rata-rata jawaban responden cenderung mengarah ke nilai tertinggi, dengan standar deviasi sebesar 5,251, artinya terjadi penyimpangan nilai dukungan manajemen puncak terhadap nilai rata-ratanya sebesar 5,251

4) Nilai minimum dari variabel implementasi Sistem Pengelolaan Keuangan Daerah (SIPKD) (Y) adalah 17 dan nilai maksimumnya sebesar 39. Rata-rata implementasi Sistem Pengelolaan Keuangan Daerah (SIPKD) adalah 33,31 dimana artinya rata-rata jawaban responden cenderung mengarah ke nilai tertinggi, dimana standar deviasi adalah 5,249, artinya terjadi penyimpangan 
nilai implementasi Sistem Pengelolaan Keuangan Daerah (SIPKD) terhadap nilai rata-ratanya sebesar 5,249.

Tabel 4 menunjukkan hasil pengujian validitas

Tabel 4.

Uji Validitas

\begin{tabular}{lcc}
\hline \multicolumn{1}{c}{ Variabel Penelitian } & Korelasi $(\mathbf{r})$ & Keterangan \\
\hline Kapasitas Sumber Daya Manusia $\left(\mathrm{X}_{1}\right)$ & $0,516 \mathrm{~s} / \mathrm{d} 0,962$ & Valid \\
Teknologi Informasi $\left(\mathrm{X}_{2}\right)$ & $0,529 \mathrm{~s} / \mathrm{d} 0,911$ & Valid \\
Dukungan Manajemen Puncak $\left(\mathrm{X}_{3}\right)$ & $0,403 \mathrm{~s} / \mathrm{d} 0,830$ & Valid \\
Implementasi SIPKD $(\mathrm{Y})$ & $0,636 \mathrm{~s} / \mathrm{d} 0,934$ & Valid \\
\hline Sumber: Data primer $(2016)$ & &
\end{tabular}

Tabel 5 memperlihatkan semua variabel dikatakan reliabel karena memiliki nilai diatas 0,60 .

Tabel 5.

\section{Uji Reliabilitas}

\begin{tabular}{lcc}
\hline \multicolumn{1}{c}{ Variabel Penelitian } & $\begin{array}{c}\text { Croncbach's } \\
\text { Alpha }\end{array}$ & Keterangan \\
\hline Kapasitas Sumber Daya Manusia $\left(\mathrm{X}_{1}\right)$ & 0,911 & Reliabel \\
Teknologi Informasi $\left(\mathrm{X}_{2}\right)$ & 0,927 & Reliabel \\
Dukungan Manajemen Puncak $\left(\mathrm{X}_{3}\right)$ & 0,796 & Reliabel \\
Implementasi SIPKD $(\mathrm{Y})$ & 0,875 & Reliabel \\
\hline
\end{tabular}

Sumber: Data primer (2016)

Hasil Tabel 6 memperlihatkan sig. adalah $(0,061>0,05)$. Sehingga menunjukkan lulus uji normalitas. 
Sang Ayu Nyoman Trisna Dewi, dan I Dewa Nyoman Badera. Dukungan Manajemen...

Tabel 6.

Uji Normalitas

\begin{tabular}{lcc}
\hline Variabel Terikat & $\begin{array}{c}\text { Kolmogorov-Smirnov } \\
\mathbf{Z}\end{array}$ & Asymp. Sig \\
\hline Implementasi SIPKD & 1,321 & 0,061 \\
\hline Sumber: Data primer (2016) & &
\end{tabular}

Tabel 7 memperlihatkan nilai sig. > 0,05 yang memiliki arti variabel dalam penelitian ini terbebas dari gejala heteroskedastisitas.

Tabel 7.

Uji Heteroskedastisitas

\begin{tabular}{lcc}
\hline \multicolumn{1}{c}{ Model } & t & Sig. \\
\hline (Constant) & 1,317 & 0,192 \\
Kapasitas Sumber Daya Manusia $\left(\mathrm{X}_{1}\right)$ & 0,997 & 0,322 \\
Teknologi Informasi $\left(\mathrm{X}_{2}\right)$ & $-0,259$ & 0,796 \\
Dukungan Manajemen Puncak $\left(\mathrm{X}_{3}\right)$ & $-1,201$ & 0,234 \\
\hline Sumber: Data primer (2016) & &
\end{tabular}

Hasil uji pada Tabel 8 memperlihatkan nilai VIF kurang dari 10 dan dan Tolerance lebih dari 0,10, sehingga lolos uji multikolinearitas.

Tabel 8.

Uji Multikolinearitas Implementasi Sistem Informasi Pengelolaan

\begin{tabular}{|c|c|c|}
\hline \multirow[t]{2}{*}{ Variabel } & \multicolumn{2}{|c|}{$\begin{array}{c}\text { Implementasi Sistem Informasi Pengelolaan } \\
\text { Keuangan Daerah } \\
\text { Collinearity Statistics }\end{array}$} \\
\hline & Tolerance & VIF \\
\hline $\begin{array}{l}\text { Kapasitas Sumber Daya } \\
\text { Manusia }\left(\mathrm{X}_{1}\right)\end{array}$ & 0,333 & 2,999 \\
\hline Teknologi Informasi $\left(\mathrm{X}_{2}\right)$ & 0,345 & 2,897 \\
\hline $\begin{array}{l}\text { Dukungan Manajemen } \\
\text { Puncak }\left(X_{3}\right)\end{array}$ & 0,803 & 1,245 \\
\hline
\end{tabular}


Tabel 9.

Uji Regresi Linear Berganda

\begin{tabular}{lccccc}
\hline \multicolumn{1}{c}{ Variabel } & \multicolumn{2}{c}{$\begin{array}{c}\text { Unstandardized } \\
\text { Coefficient }\end{array}$} & $\begin{array}{c}\text { Standardized } \\
\text { Coefficient }\end{array}$ & Sig \\
& B & $\begin{array}{c}\text { Std. } \\
\text { Error }\end{array}$ & Beta & T & Sig \\
\hline Constant & 2,034 & 1,920 & & 1,059 & 0,293 \\
Kapasitas SDM $\left(\mathrm{X}_{1}\right)$ & 0,288 & 0,067 & 0,405 & 4,310 & 0,000 \\
Teknologi Informasi $\left(\mathrm{X}_{2}\right)$ & 0,200 & 0,067 & 0,274 & 2,967 & 0,004 \\
Adjusted Rsquare: 0,797 & & & & & \\
Fhitung: 91,047 & & & & \\
Sig. Fhitung: 0,000 & & & &
\end{tabular}

Tabel 9. menunjukan persamaan dalam penelitian ini, yaitu:

$\hat{Y}=2,034+0,288 X_{1}+0,200 X_{2}+\varepsilon$

Berdasarkan persamaan regresi dapat diketahui bahwa, nilai konstanta sebesar 2,034 artinya apabila kapasitas sumber daya manusia dan teknologi informasi meningkat maka implementasi SIPKD akan meningkat pula.

Nilai koefisien regresi kapasitas sumber daya manusia dan teknologi informasi masing-masing sebesar 0,288 dan 0,200 memiliki arti apabila kapasitas sumber daya manusia dan teknologi informasi meningkat, maka implementasi SIPKD akan meningkat pula dengan asumsi variabel lainnya konstan. 
Tabel 10.

Uji Regresi Moderasi

\begin{tabular}{|c|c|c|c|c|c|c|}
\hline \multirow{2}{*}{\multicolumn{2}{|c|}{ Variabel }} & \multicolumn{2}{|c|}{$\begin{array}{l}\text { Unstandardized } \\
\text { Coeficients }\end{array}$} & \multirow{2}{*}{$\begin{array}{c}\text { Standardized } \\
\text { Coefficients } \\
\text { Beta } \\
\end{array}$} & \multirow[b]{2}{*}{ t } & \multirow[b]{2}{*}{ Sig } \\
\hline & & B & $\begin{array}{l}\text { Std. } \\
\text { Error }\end{array}$ & & & \\
\hline \multicolumn{2}{|c|}{ Kapasitas Sumber Daya Manusia $\left(\mathrm{X}_{1}\right)$} & 0,637 & 0,264 & 0,898 & 2,412 & 0,019 \\
\hline \multicolumn{2}{|c|}{ Teknologi Informasi $\left(\mathrm{X}_{2}\right)$} & 1,854 & 0,345 & 2,544 & 5,369 & 0,000 \\
\hline \multirow{2}{*}{\multicolumn{2}{|c|}{$\begin{array}{l}\text { Dukungan Manajemen } \operatorname{Puncak}\left(\mathrm{X}_{3}\right) \\
\mathrm{X}_{1} \mathrm{X}_{3}\end{array}$}} & 1,989 & 0,426 & 1,989 & 4,669 & 0,000 \\
\hline & & 0,022 & 0,008 & 1,315 & 2,543 & 0,013 \\
\hline \multicolumn{2}{|l|}{$\mathrm{X}_{2} \mathrm{X}_{3}$} & 0,058 & 0,012 & 3,513 & 4,905 & 0,000 \\
\hline Constant & $=-29,546$ & & & & & \\
\hline $\mathrm{R}$ & $=0,927$ & & & & & \\
\hline R Square & $=0,859$ & & & & & \\
\hline \multicolumn{7}{|c|}{ Adjusted $R^{2}=0,848$} \\
\hline $\mathrm{F}_{\text {hitung }}$ & $=77,825$ & & & & & \\
\hline Sig. & $=0,000$ & & & & & \\
\hline
\end{tabular}

Sumber: Data primer (2016)

Tabel 10. Menunjukkan model regresi moderasi penelitian ini, yaitu:

$\hat{Y}=-29,546+0,637 X_{1}+1,854 X_{2}+1,989 X_{3}+0,022 X_{1} X_{3}+0,058 X_{2} X_{3}+\varepsilon$

Berdasarkan persamaan regresi di atas dapat diketahui bahwa. nilai konstanta sebesar -29,546 artinya apabila kapasitas sumber daya manusia dan teknologi informasi konstan, maka implementasi SIPKD akan meningkat. Nilai koefisien regresi dukungan manajemen puncak memperkuat pengaruh kapasitas sumber daya manusia sebesar 0,022 memiliki arti apabila dukungan manajemen puncak memperkuat kapasitas sumber daya manusia, maka implementasi SIPKD akan meningkat (asumsi variabel lain kostan). Nilai koefisien regresi dukungan manajemen puncak memperkuat pengaruh teknologi informasi sebesar 0,058 memiliki arti apabila dukungan manajemen puncak memperkuat teknologi informasi, maka implementasi SIPKD akan meningkat (asumsi variabel lain kostan). 
Berdasarkan hasil regresi moderasi pada Tabel 10, Uji F-test memiliki signifikansi sebesar 0,000 lebih kecil dari $\alpha=0,05$. Hal ini menunjukkan bahwa variabel kapasitas sumber daya manusia, teknologi informasi, moderasi $\mathrm{X}_{1} \mathrm{X}_{3}$ (kapasitas sumber daya manusia dan dukungan manajemen puncak), serta moderasi $\mathrm{X}_{2} \mathrm{X}_{3}$ (teknologi informasi dan dukungan manajemen puncak) secara bersama-sama mampu memprediksi atau menjelaskan implementasi sistem informasi pengelolaan keuangan daerah.

Pada Tabel 10 dapat diketahui nilai adjusted $\mathrm{R}^{2}=0,848$, yang mengandung pengertian bahwa $84,8 \%$ variabel implementasi sistem informasi pengelolaan keuangan daerah dapat dijelaskan oleh variabel kapasitas sumber daya manusia dan teknologi informasi sedangkan sisanya sebesar 15,2 persen dipengarui oleh variasi faktor-faktor lain yang tidak masuk dalam model persamaan regresi penelitian.

Pengujian hipotesis dapat dilihat dari hasil uji t pada Tabel 9 dan Tabel 10 menunjukkan koefisien nilai kapasitas sumber daya manusia (X1) adalah 0,288, besar $\mathrm{t}$ hitung 4,310 dengan signifikansi 0,000 yang lebih kecil dari alpha $(\alpha=0,05)$, hal ini berarti kapasitas sumber daya manusia berpengaruh positif pada implementasi SIPKD di Pemerintah Kota Denpasar. Sehingga hipotesis pertama penelitian ini yang menyatakan kapasitas sumber daya manusia berpengaruh positif pada SIPKD dapat diterima.

Hasil koefisien teknologi informasi (X2) memiliki nilai 0,200, t hitung sebesar 2,967 dan signifikan 0,004, ini berarti teknologi informasi berpengaruh 
positif pada SIPKD di Pemerintah Kota Denpasar, yang menyatakan teknologi informasi berpengaruh positif pada implementasi SIPKD dapat diterima.

Hasil koefisien interaksi variabel kapasitas sumber daya manusia (X1) dan dukungan manajemen puncak (X3) bernilai 0,022, dengan t hitung 2,543 dan signifikan 0,013, artinya hipotesis ketiga dalam penelitian ini yang menyatakan dukungan manajemen puncak meningkatkan pengaruh kapasitas sumber daya manusia pada implementasi SIPKD di Pemerintah Kota Denpasar dapat diterima. Hal ini berarti, dukungan manajemen puncak dapat dikategorikan sebagai jenis Quasi moderator (moderasi semu).

Hasil koefisien interaksi variabel teknologi informasi (X2) dan dukungan manajemen puncak (X3) bernilai 0,058, dengan t hitung 4,905 dan signifikan adalah 0,000. Artinya dukungan manajemen puncak memperkuat pengaruh teknologi informasi pada implementasi SIPKD, sehingga hipotesis keempat dalam penelitian ini dapat diterima. Hal ini berarti, dukungan manajemen puncak dapat dikategorikan sebagai jenis Quasi moderator (moderasi semu).

\section{SIMPULAN DAN SARAN}

Simpulan yang diperoleh adalah sebagai berikut.

1) Kapasitas sumber daya manusia meningkatkan dan berpeluang lebih tinggi atas keberhasilan implementasi SIPKD di Pemerintah Kota Denpasar. Hal ini berarti, jika sumber daya manusia semakin baik maka akan memperbaiki sistem akuntansi agar mampu mengimplementasikan sistem informasi pengelolaan keuangan daerah di Pemerintah Kota Denpasar dengan baik. 
2) Teknologi Informasi meningkatkan dan berpeluang lebih tinggi atas keberhasilan implementasi sistem informasi pengelolaan keuangan daerah. Hal ini mengandung makna bahwa teknologi informasi yang canggih, teknologi yang modern dapat mendukung kelangsungan kerja para pegawai sehingga pegawai mampu menghasilkan laporan keuangan yang tepat waktu, akurat, terpercaya, dan secara tidak langsung pegawai mau menerima, menggunakan, dan berhasil mengimplementasikan sistem informasi pengelolaan keuangan daerah di Pemerintah Kota Denpasar.

3) Dukungan manajemen puncak meningkatkan dan berpeluang lebih tinggi atas pengaruh kapasitas sumber daya manusia pada implementasi sistem informasi pengelolaan keuangan daerah. Hal ini mengandung makna, bahwa dukungan manajemen puncak akan meningkatkan kualitas sumber daya manusia dengan kemampuan seorang manajer yang dimilikinya dalam mengelola, mengembangkan dan berpartisipasi aktif dalam penerapan sistem informasi serta menjadi kunci keberhasilan implementasi sistem informasi pengelolaan keuangan daerah di Pemerintah Kota Denpasar.

4) Dukungan manajemen puncak meningkatkan dan berpeluang lebih tinggi atas pengaruh teknologi informasi pada implementasi sistem informasi pengelolaan keuangan daerah. Hal ini mengandung makna, bahwa dukungan manajemen puncak akan meningkatkan teknologi informasi, seperti penyediaan dana anggaran, penyediaan perangkat lunak maupun keras dari teknologi informasi sehingga dapat membantu penerapan sistem 
Sang Ayu Nyoman Trisna Dewi, dan I Dewa Nyoman Badera. Dukungan Manajemen...

informasi serta memungkinkan pegawai untuk menerima, mampu berpartisipasi dalam setiap kegiatan pengelolaan keuangan demi keberhasilan implementasi sistem informasi pengelolaan keuangan daerah. Berdasarkan hasil penelitian dan kesimpulan, berikut ini beberapa saran untuk keberhasilan implementasi SIPKD di Pemerintah Kota Denpasar melalui kapasitas sumber daya manusia, teknologi informasi dan dukungan manajemen puncak sebagai berikut.

1) Satuan Kerja Perangkat Daerah di Pemerintah Kota Denpasar diharapkan mampu mempertahankan hal positif yang telah diterapkan sebelumnya, dan melakukan peningkatan terhadap hal-hal yang masih kurang dalam usaha mendukung pengimplementasian SIPKD di Pemerintah Kota Denpasar.

(1) Pemberian kualifikasi pendidikan yang cukup dengan pemberian pelatihan dan workshop diharapkan dapat terus dipertahankan untuk dapat menunjang implementasi aplikasi sistem informasi pengelolaan keuangan daerah. Namun, pengalaman pegawai mengenai software dan hardware dirasakan perlu untuk diperhatikan di setiap Satuan Kerja Perangkat Daerah serta disiplin pegawai dalam bekerja seharusnya sesuai dengan prosedur akuntansi.

(2) Perhatian setiap Satuan Kerja Perangkat Daerah atas peralatan yang telah usang atau rusak dapat cepat didata dan diperbaiki tepat pada waktunya, ini berarti pegawai dapat menyelesaikan pekerjaan tanpa menunggu lama peralatan teknologi informasi yang dibuuhkan. 
Terbukti dengan Kota Denpasar memperoleh penghargaan sebagai kota pintar dalam penerapan teknologi informasi. Akan tetapi, perlu ditingkatkan disiplin pegawai dalam penggunaan teknologi informasi yang disediakan, sebab teknologi informasi yang disediakan seperti jaringan internet digunakan untuk kepentingan pribadi, untuk itu harus diperhatikan oleh setiap SKPD Kota Denpasar.

(3) Pimpinan memenuhi keperluan kebutuhan sumber daya manusia untuk menunjang penggunaan sistem informasi dan pimpinan menyediakan akses atas berbagai software ketika pegawai membutuhkannya. Hanya saja, pimpinan tidak peduli terhadap manfaat yang diberikan melalui penggunaan sistem informasi. Untuk itu, diharapkan pimpinan lebih memperhatikan pelaksanaan sistem informasi demi mewujudkan keberhasilan implementasi SIPKD.

2) Variabel yang digunakan dalam penelitian selanjutnya untuk menguji keberhasilan implementasi SIPKD dapat lebih bervariasi, seperti pengalaman dan masa kerja serta variabel moderasi lain seperti pelatihan, pendidikan dan budaya organisasi, sehingga dengan demikian akan tercapai penelitian yang diharapkan oleh peneliti. Disarankan untuk menambahkan metode lain selain kuisioner seperti wawancara langsung sehingga peneliti dapat meyakini jawaban yang diberikan responden menggambarkan keadaan yang sebenarnya dan menghindari ketidakpengembalian kuesioner dengan jumlah besar. 


\section{REFERENSI}

Abernethy, Margaret A., Peter, Brownell. 1999. The Role of Budgets in Organizations Facing Strategic Change: An Exploratory Study. Accounting Organizations and Society : pp. 189-204.

Alimbudiono, Ria Sandra dan Fidelis Arastyo Andono. 2004. Kesiapan Sumber Daya Manusia Sub Bagian Akuntansi Pemerintah Daerah "XYZ" dan Kaitannya Dengan Pertanggungjawaban Keuangan Daerah Kepada Masyarakat: Renungan Bagi Akuntan Pendidik. Jurnal Akuntansi dan Keuangan Sektor Publik.Vol. 05 No. 02 : Hal.18-30.

Almilia, Luciana Spica dan Irmaya Briliantien. 2007. Faktor-Faktor Yang Mempengaruhi Kinerja Sistem Informasi Akuntansi Pada Bank Umum Pemerintahan di Wilayah Surabaya dan Sidoarjo. Jurnal Akuntansi. Vol. 10 No.1.

Ang, C. L., Davies, M. A., and Finlay, P. N. 2001. An Empirical Model of IT Usage in The Malaysian Public Sector. Journal of Strategic Information Systems.10: 159- 174.

Amran. 2009. Pengaruh Disiplin Kerja Pegawai Kantor Departemen Social Kabupaten Gorontalo. Jurnal Ichan Gorontalo : Hal 2397.

Aplonia, Elfreda. 2003. Pengaruh Partisipasi Pemakai terhadap Kepuasan Pemakai Dalam Pengembangan Sistem Informasi dengan Lima Variabel Moderating. Jurnal SNA VI.

Arad, Hamed and Hoda Arad. 2009. Information Technology and Internal Controls. SSRN Digital Library, Information Systems and Technology. USA.

Arfan, Ikhsan L. 2003. Tinjauan Involvement Peran Top Manajemen, Software Developers serta Penggunaan TAM (Technology Acceptance Model) dalam Pengembangan TI dan Sistem Informasi Akuntansi Berbasis Komputer. Jurnal Ekonomi dan Bisnis. Vol. 4, No. 2 Juli : pp. 153 - 164.

Arsanti, T. A. 2009. Hubungan Antara Penetapan Tujuan, Self-Efficacy dan Kinerja. Jurnal Bisnis dan Ekonomi : 16 (2).

Atyanta, Ramya. 2011. Analisis Opini BPK atas Laporan Keuangan Pemerintah Daerah (Studi Kasus pada Kabupaten X di Jawa Timur). Jurnal Ilmiah : hal 16.

Azhar. 2007."Faktor-Faktor yang Mempengaruhi Keberhasilan Penerapan Permendagri No.13 Pada Pemerintah Kota Banda Aceh" (tesis). Medan: Universitas Sumatera Utara. 
Azzara, C.V. 2010, Questionnaire Design for Business Research. Tate Publishing. USA.

Baig, A. H. and Gururajan, R. 2011. Preliminry Study to Investigation the Determinants that Effect IS/IT Outsourcing. Journal of Information and Communication Technology Research, 1 (2), pp: 48-54.

Bagoe, Femi. 2009. Pengaruh Penerapan Sistem Informasi Pengelolaan Keuangan Daerah (SIPKD) Terhadap Efektivitas Pengelolaan Keuangan Daerah (Studi Pada Dppkad Kota Gorontalo). Jurnal.

Blerkom, Van M.L. 2009. Measurement and Statistics for Teacher. New York: Routledge

Bentley, Lonnie D and Whitten, Jeffrey L. 2007. Systems Analysis and Design for the Global Enterprise. International Edition. McGrawHill, New York.

Berardine, T. 1997. Human Resource Information Systems Improve Management Decision Making. The Canadian Manager.

Bodnar, H. George and William S. Hopwood Amir Abadi Jusuf, and Rudi M. Bouwens, J., \& Abernethy, M. A. 2006. The Consequences of Customization of Management Accounting System Design. Accounting Organization and Society, 24 (2) :221 - 241.

Bouwens, Mark. 2007. Analyzing and Assessing Public Accountability. A Conceptual Framework. European Law Journal, 13(4) : p. 837-868.

Celviana Widyaningrum, Rahmawati. 2010. Pengaruh SDM, dan Pemanfaatan Teknologi Informasi Terhadap Keterandalan dan Ketepatwaktuan Pelaporan Keuangan Pemerintah Daerah dengan Variabel Intervening Pengendalian Intern Akuntansi, Studi Empiris di Pemda Subosukawonosraten. Simposium Nasional Akuntansi XII Purwokerto.

Chang, Y. W. 2001. "The Effects of Environment, Strategy and Organizational Characteristics on the Performance of Accounting Information Systems" (Unpublished PhD thesis). University of Chicago.

Choe, J.M., 1996. The Relationships Among Performance of Accounting Information Systems, Influence Factors, and Evolution Level of Information Systems. Journal of Management Information System/Spring.Vol. 12 No. 4. pp. 215-239. Comparison of Two Theoritical Models. Management Science, 35 (8): p.982-1002. 
Cindy, A. \& Ros, Yuni Bangun. 2014. The Impact Of Information System Implementation in Enhancing the Effecttiveness and Efficiency of Travel Mangement Business Process. Journal of Business and Management.Vol. 3No. 4: Pp. 420-431.

Compeau, D. R., \& Higgins, C. A. 1995. Computer self-efficacy: Development of a measure and initial test. MIS quarterly: 189-211.

Danardono, MPH, Dr. 2013. Sejarah Perkembangan Teorema Limit Pusat. Fakultas Matematika dan Ilmu Pengetahuan Alam. Yogyakarta: Universitas Gajah Mada.

Darise, Nurlan. 2009. Pengelolaan Keuangan Daerah. Indeks. Jakarta.

Darono, Agung. 2009. Aplikasi Excel Sebagai Perangkat Bantu Audit. Jakarta.

Davis, Keith K dan Wearther, B. 1989. Human Resources and Personel Management. New York : Mc Graw- Hill Book Company.

Dellano Villanueva, Abbas Mirakhor. 2012. Strategies for Financial Reforms: Interest Rate Policies, Stabilization and Bank Supervision in Developing Countries. Published by: Palgrave Macmillan Journals on behalf of the International Monetary Fund Vol. 37, No. 3: pp. 509-536.. Stable URL: http://www.jstor.org/stable/3867263.

DeLone W. H. and McLean E. R. 1989. The DeLone and McLean Model of Information Systems Success: a ten-year update. Journal of Management Information Systems. 19(4) : 9-30.

DeLone, William H. 1988. Determinants of Success for Computer Usage in Small Business. MIS Quarterly, March, 12, 1 : pp. 51-61.

Dewi, P. Ayu Ratna. 2014. Pengaruh Efektivitas Penerapan Sistem Informasi Pengelolaan Keuangan Daerah (SIPKD) Pada Kualitas Laporan Keuangan. E-Jurnal Akuntansi Universitas Udayana. ISSN: 2302-8556. 8.3(2014):442-457.

Dhany, Chindra Triwulan. 2010. Penerapan Model Pembelajaran Quantum Teaching untuk Meningkatkan Hasil Belajar IPS Siswa Kelas IV SD Negeri 145 Pekanbaru Tahun 2012. Jurnal. Tersedia dalam : URL :

http://fkipuny.ac.id/ejurnal/index.php/pgsd/article/view/2012.Diakses tanggal 23 Mei 2013.

Dian, Indri Purnamasari. 2004. Analisis Faktor-faktor yang Mempengaruhi Keefektifan Pengembangan Sistem Informasi. Jurnal Widya Manajemen dan Akuntansi, Vol. 4 No. 2. Agustus : 218-235. 
Doll. W. J. Dan G, Torkzadeh. 1986. A Discrepancy Model of End-User Computing Involvement, and Usefulness of Information System. Decision Sciences. Vol. 17. No. 4.

Doms, M. E., Jarmin, R. S. and Klimek, S. D. 2004. Information Technology Investment and Firm Performance in U.S. Retail Trade. Economics of Innovation and New Technology,13(7) : 595-613.

Fontanella, Amy dan Rossieta, Hilda. 2014. Pengaruh Desentralisasi Fiskal dan Kinerja Terhadap Akuntabilitas Pelaporan Keuangan Pemerintah Daerah di Indonesia. SNA XVII Makalah Nomor 175. Available from: URL : http://multiparadigmalecture.ub.ac.id, diakses pada 19 Desember 2014.

Forum Dosen Akuntansi Sektor Publik. 2006. Standar Akuntansi Pemerintahan: Telaah Kritis PP Nomor 24 Tahun 2004. Yogyakarta : BPFE.

Ghozali, Imam. 2011. Aplikasi Analisis Multivariate dengan Program IBM SPSS 19. Semarang: Universitas Diponegoro.

Ghozali, Imam. 2013. Applications Multivariate Analysis with SPSS Program. Issue 5. Semarang: Publisher Agency Diponegoro University.

Govindarajan, V. 1986. Impact of Participation in The Budgetary Process on Management Attitudes and Performance: Universalistic and Contigency Perspectives. Decision Sciences : pp. 496 -516.

Gwendolyn Combs, Fred Luthans, and Jakari Griffith. 2009. Learning Motivation And Transfer Of Human Capital Development. Implications From Psychological Capital. Published in The Peak Performing Organization, ed. Ronald J. Burke and Cary L. Cooper (London \&New York: Routledge/Taylor \& Francis, 2009), pp: 73-91. University of Nebraska Lincoln.

Hall, James A. 2009. Sistem Informasi Akuntansi. Edisi Keempat. Jakarta: Salemba Empat.

Handoko, Hani T, Dr.MBA dan Reksohadiprodjo Sukanto, Dr. M.Com.1996. Organisasi Perusahaan. Edisi kedua Yogyakarta : BPFE

Hendra, P Darmawan, Yulita Setiawanta, SE, M.Si, Ira Septriana, SE, M.Si. 2015. Analisis Pengaruh Keterlibatan Pemakai Dalam Pengembangan Sistem Informasi, Dukungan Manajemen Puncak, Dan Formalisasi Pengembangan Sistem Informasi Terhadap Kinerja Sistem Informasi Akuntansi Pada Pt. Bank Jateng Cabang Ungaran. Jurnal. 
Hevesi, G. Alan. 2005. Standards for Internal Control in New York State Government. Journal. Available from : URL : www.osc.state.ny.us. http://www.kemendagri.go.id/pages/sipkd/sistem-informasi-pengelolaankeuangan-daerah-sipkd

Huda, Ulul. 2009. Hubungan Teknologi Informasi dan Komunikasi dengan Kekuasaan Lokal: Sebuah Penilaian Mengenai Dampak yang Ditimbulkan. Tersedia dalam: URL http://ululbanyuwangi.blog.com/2009/10/16/hubungan-teknologi informasi-dan-komunikasi-dengan-kekuasaan-lokal-sebuah-penilaianmengenai-dampak-yang-ditimbulkan/. diakses 20 April2011.

Husni. 2010. "Pengaruh Kualitas Sumber Daya Manusia dan Akuntabilitas Kinerja Terhadap Pengelolaan Keuangan Daerah Studi di SKPD Pemerintah Kota Banda Aceh". (tesis). Universitas Syiah Kuala.

Indriantoro, Nur, Bambang Supomo. 2002. Metodelogi Penelitian Bisnis. Edisi Pratama. Yogyakarta: BPFE.

Indriasari, Desi dan Ertambang Nahartyo. 2008. Pengaruh Kapasitas Sumber Daya Manusia, Pemanfaatan Teknologi Informasi dan Sistem Pengendalian Intern Terhadap Nilai Informasi Pelaporan Keuangan Pemerintah Daerah. Jurnal SNA. Politeknik Negeri Sriwijaya Palembang.

Igbaria, M., Zinatelli, N., Cragg, P. \& Cavaye, L.M. 1997. Personal Computing Acceptance Factors in Small Firms: A Structural Equation Model. MIS Quarterly 21(3): 279-302.

Irmadhani, I. 2012. Pengaruh Persepsi Kebermanfaatan, Persepsi Kemudahan Penggunaan dan Computer Self Efficacy, terhadap Penggunaan Online Banking pada Mahasiswa S1 Fakultas Ekonomi Universitas Negeri Yogyakarta. Kajian Pendidikan \& Akuntansi Indonesia.

Jarvenpaa S.L. and Ives, Blake. 1991. Executive Involvement and Participation in the Management of Information Technology. MIS Quarterly.Vol. 15, No. 2 : pp. 205-227.

Jogiyanto, HM. 2009. Analisis dan Desain. Yogyakarta : Andi OFFSET.

Jogiyanto. 2007. Metodelogi Penelitian Bisnis: Salah Kaprah dan PengalamanPengalaman. Yogyakarta: BPFE.

Jurnali, T. \& Bambang Supomo. 2002. Pengaruh Faktor Kesesuaian TugasTeknologi dan Pemanfaatan TI terhadap Kinerja Akuntan Publik.Jurnal Riset Akuntansi Indonesia. Vol. 5 No. 2: Hal. 214-228. 
Kartana, I Wayan. 2008. "Pengujian Kesuksesan Pengembangan Sistem Informasi Managemen Daerah di Pemerintah Kota Jogyakarta" (tesis). Yogyakarta: Universitas Gajah Mada.

Kavanagh, M. J., \& Thite, M. 2009. United States of America: SAGE Publications Inc.

Kerlinger, F.N. 2003. Asas-Asas Penelitian Behavioral (3th ed). Yogyakarta : Gajah Mada University Press.

Koch, Milos. 2012. Verification of Selected Weak Points of Information System in Terms of Other Parameters as A Part of Ict Effectiveness Evaluation. Journal of Business Systems and Economics, No. 2 (1). Brno University Of Technology Faculty Of Business And Management :Department of informatics.

Komara, Acep. 2005. Analisis Faktor-Faktor Yang Mempengaruhi Kinerja Sistem Informasi Akuntansi. Jurnal Ilmiah Universitas Swadaya Gunung Jati. Cirebon.

Kharis, Abdul. 2010. Pengaruh Kualitas SumberDaya manusia Terhadap Pelaksanaan Sistem Pengendalian Intern pada PT. Avia Avian. Skripsi. UPN Veteran. Jawa Timur.

Khoirum Novita Rizkiana. 2013. Pengaruh Partisipasi Pemakai Terhadap Kepuasan Pemakai Dalam Pengembangan Sistem Informasi Dengan Dukungan Manajemen Puncak, Komunikasi Pemakai pengembang, Pengaruh Pemakai Sebagai Moderating Variabel. Naskah Publikasi. Universitas Muhammadiyah Surakarta.

Kim, E dan J. Lee. 1986. An Exploratory Contigency Model of User Participation and MIS Use. Journal of Information and Management.Vol. 11, No.2.

King, W., dan Teo, T. 1996. Key Dimensions of Facilitors and Inhibitors for the Strategic Use of Information Technology. Journal of Management of Information Systems, 12 (4): 35-53.

Kriyanto, Rachmat. 2008. Teknik Praktis Riset Komunikasi: Disertai Contoh Praktis Riset Media, Public Relations, Advertising, Komunikasi Organisasi, Komunikasi Pemasaran. Jakarta: Kencana Prenada Media Group.

Lamb, R, R. Kling. 2004. Reconceptualizing User as Social Actors in Information Systems Research. Jurnal MIS Quarterly. Vol. 27, No. 2: pp.197-236. 
Liana.2009

Lau, Elfreda Aplonia. 2003. Pengaruh Partisipasi Pemakai Terhadap Kepuasan Pemakai dalam Pengembangan Sistem Informasi dengan Lima Variabel Moderating. Jurnal Simposium Nasional Akuntansi VI (Online). Vol. 7, No. 1: 16-17 Oktober.

Laudon, Kenneth C. Dan Jane P. Laudon. 2008. Management Information System Managing the Digital Firm. Terjemahan Chriswan Sungkono \& Machmudin Eka P. Jakarta Salemba Empat.

Liana. 2009. Corporate Sosial Responsbility (CSR) : Tinjauan dan praktik di Indonesia. Fakultas Ekonomi Universitas Kristen Maranatha.

Lindawati, Hj dan Irma Salamah. 2012. Pemanfaatan Sistem Informasi dan Teknologi Informasi Pengaruhnya Terhadap Kinerja Individual Karyawan. Jurnal Akuntansi Dan Keuangan, Vol. 14, No. 1, Mei 2012: 56-68. Politeknik Negeri Sriwijaya.

Livari, Juhani. 2005. An Empirical Test of the DeLone-McLean Model of Information System Success. Database for Advance in Information System (DFA).Journal. ISSN : 1532- 0936, Volume 36. ProQuest Company.

Livari, J, and Ervasti, I. 1994. User Information Satisfaction: IS Implementability and Effectiveness. Information \& Management, Vol. 27, No. 4: pp. 205-220.

Lucas, H.C., Jr. 1999. Information Technology and the Productivity Paradox: Assessing the Value of Investing in IT. New York: Oxford University Press.

Maharsi. 2000. Pengaruh Perkembangan Teknologi Informasi Terhadap Bidang Akuntansi Manajemen. Jurnal Akuntansi \& Keuangan, Vol. 2, No. 2, Nopember 2000: 127.

Manivannan, S. \& Wan Nur Azah. 2011. The Impact of Knowledge Management on Accounting. Intrnational Journal of Innovative Research in Science and Techniques, Vol. 2.No. 1: Pp. 45-49.

Mardiasmo. 2006. Akuntansi Sektor Publik (Edisi Kedua). Yogyakarta: Andi.

Martin, E. 1999. Managing Information Technology. What Managers Need to Know. 3rd edition. New Jersey: Pearson Education International.

Marzuki. 2005. Metodologi Riset. Yogyakarata: Ekonisia. 
Masodah. 2014. The Effect of User Partisipation on The AIS Performance With Top Management Support, Tax Complexity, System Complexity, And User Expertise As A Moderating Variable. Jornal Economics \& Business Research Festival. Universitas Gunadarma.

Mulyadi, dan Setyawan, Jhony. 2000. Sistem Perencanaan dan Pengendalian Manajemen. Aditya Media. Jogyakarta.

Munasinghe, L. 2004. Factors Influencing IT Applications in Small and Medium Scale Industries in Developing Countries : Case of Sri Lanka. Journal. Available from: URL : http://www.Irv.ufsc.br/IFIP-WG-9.5/Ifipcd/1b6.html.

Murray, D. 1990. The Performance Effects of Participative Budgeting, an Interpretation of Intervening and Moderating Variables. Behavioral Research in Accounting, Vol. 2 : pp.104-123.

Nihayah, Anisatin. 2015. Pengaruh Sumber Daya Manusia, Pemanfaatan Teknologi Informasi, Pengendalian InternalTerhadap Ketepatwaktuan Dan Keterandalan Pelaporan Keuangan Pemerintah Daerah. Naskah Publikasi. Universitas Muhammadiyah Surakarta.

Novita. 2015. Penerapan Sistem Informasi Manajemen pada SIPKD. Tersedia dalam: URL:

www.google.com. http://novitaoki.blogspot.com/2015/01/penerapan-sisteminformasi-manajemen.html.

Nurillah, As Syifa. 2014. Pengaruh Kompetensi Sumber Daya Manusia, Penerapan Sistim Akuntansi Keuangan Daerah, Pemanfaatan Teknologi Informasi dan Sistem Pengendalian Intern Terhadap Kualitas Laporan Keuangan Pemerintah Daerah. Jurnal Ekonomi Akuntansi. Universitas Diponegoro.

O’Brien JA, Marakas G. 2009. Management Information sistem. Ninth edition. Boston: Mc Graw Hill, Inc.

Orlikowski, W., \& Gash, D. 1992. Changing frames: Understanding technological change in organizations. Center for Information Systems. Massachusetts Institute of Technology.

Peraturan Menteri Dalam Negeri No.13 Tahun 2006 mengenai Modul Pelaksana APBD - SIPKD.

Pirade, D., Saleh, A. K., Amar, M. Y., \& Pendapatan, S. D. 2013. Pengaruh Penggunaan Sistem Informasi Pengelolaan Keuangan Daerah (Sipkd) Terhadap Kinerja Pegawai Di Kabupaten Tana Toraja. Jurnal Analisis, Vol. 2 (2). 
Rahadi, D. Rianto. 2007. Peranan Sistem informasi dan sistem informasi dan teknologi informasi dalam Peningkatan Pelayanan di Sektor Publik. Seminar Nasional Teknologi 2007 (SNT 2007). Yogyakarta 24 November 2007.

Rahman, Dicky. 2015. Pengaruh Pemanfaatan Teknologi Informasi, Penerapan Sistem Akuntansi Keuangan Daerah, Dan Penerapan Standar Akuntansi Pemerintahan Terhadap Kualitas Laporan Keuangan Daerah (Studi Empiris Pada Skpd Provinsi Riau). Jom FEKON, Vol. 2.

Ramezan, Majid. 2009. Measuring Thece Effectiveness of Human Resource Information System in National Iranian Oil Company (An Empirical Assesment). Iranian Journal of Management Studies, 2(2): h.129-145.

Rantanen, H., et. al. 2007. Performance Measurement System in The Finnish Public Sector. Internationel Journal of Public Sector Management, Vol. 20 No. 5: pp. 415-433.

Ratnaningsih, Indah Kadek dan I Gusti Ngurah Agung Suaryana. 2014. Pengaruh Kecanggihan Teknologi Informasi, Partisipasi Manajemen, dan Pengetahuan Manajer Akuntansi Pada Efektivitas Sistem Informasi Akuntansi. ISSN: 2302-8556. E-Jurnal Akuntansi Universitas Udayana 6.1 (2014):1-16.

Republik Indonesia, Peraturan Pemerintah Nomor 24 Tahun 2005 tentang Standar Akuntansi Pemerintahan.

Republik Indonesia, PeraturanPemerintah Nomor 56 Tahun 2005 tentang Sistem Informasi Keuangan Daerah.

Republik Indonesia, Peraturan Pemerintah Nomor 71 Tahun 2010 tentang Standar Akuntansi Pemerintahan.

Romney, Paul, and John, Steinbart. 2014. Accounting Information System. Ninth Edition: Prentice Hall.

Rosen, L., \& Michelle, W. 1995.Computer availability, computer experience and technophobia among public school teachers. Computer in Human Behaviour, 11: 9-31.

Saktiyanto, A.M. Heri. 2013. Faktor - Faktor Yang Mempengaruhi Kegagalan Dan Keberhasilan Dalam Penerapan Sistem Informasi Pada Perusahaan. Tugas mata kuliah. Pascasarjana Manajemen Dan Bisnis Institut Pertanian Bogor. 
Samuel Ereyi Aduwa Ogiegbaen, Ede Okhion Sunday Iyamu. 2005.Using Information and Communication Technology in Secondary Schools in Nigeria: Problems and Prospects. Educational Technology \& Society, 8 (1) : 104-112. University of Benin City Nigeria.

Santiadji Mustafa, Sutrisno, Rosid. 2010. Analisis Faktor- Faktor Yang Berpengaruh TerhadapKeterandalanDan Ketepatwaktuan Pelaporan Keungan Pada SKPD Pemerintah Daerah Kota Kendari. Jurnal Akuntansi.

Sarosa, Samiaji dan Zowghi, Didar. 2003. Strategy for Adopting Information Technology for SMEs : Experience in Adopting Email Within an Indonesian furniture Company. Electronic Journal of Information Syatems Evaluation. Vol. 6 Issue 2: pp. 165 - 176.

Sekaran, Uma. 2006. Metodologi penelitian Untuk bisnis. Jakarta: Salemba empat.

Setianingsih, Sunarti. 1998. "Pengaruh Dukungan Manajemen Puncak dan Komunikasi Pemakai Pengembang Terhadap Hubungan Partisipasi dan Kepuasan Pemakai dalam Pengembangan Sistem Informasi” (tesis). Universitas Gadjah Mada.

Simanjuntak, Mangatas 2013. Faktor-Faktor Yang Mempengaruhi Keberhasilan Dan Kegagalan Penerapan Sistem Informasi Pada Suatu Perusahaan. Tugas Mata Kuliah Sistem Informasi Manajemen. Program Pascasarjana Manajemen Dan Bisnis Institut Pertanian Bogor.

Shields KA, Cummings N, Curran JE, Comuzzie AG. 1995. Chemerin is associated with metabolic syndrome phenotypes in a Mexican-American population. J Clin Endocrinol Metab. 94 : 3085-3088.

Simon. M.A. 1995. Developing New Models of Mathematics Teaching: An Imperative for Research on Mathematics Teacher Development. Dalam E. Fennema \& B.S. Nelson (EDs.). Mathematics Teachers in Transition: pp. 55- 86. Mahwah, NJ: Lawrence Erlbaum Associates.

Soegiharto. 2001. Influence Factors Affecting The Performance of Accounting Information System. Gajah Mada International Journalof Business, Vol. III No. 2.

Sri Maharsi. 2000. Pengaruh Perkembangan TeknologiInformasi Terhadap BidangAkuntansi Manajemen. Jurnal Akuntansi \& Keuangan,Vol. 2, No. 2, Nopember 2000: 127 - 137. Universitas Kristen Petra.

Sumanto. 2014. Teori Dan Aplikasi Metode Penelitian. Jakarta: Center of Academic Publishing Service. 
Suma, Arif. 2010. "Pengaruh Kapasitas Sumber Daya Manusia (Sdm) Terhadap Implementasi Sistem Akuntansi Instansi (SAI) Di Komisi Pemilihan Umum Provinsi Gorontalo" (tesis). Gorontalo : Universitas Negeri Gorontalo.

Sugiyono. 2015. Metode Penelitian Tindakan Komprehensif. Bandung: Alfabeta.

Supriyanto. 2005. Pengantar teknologi Informasi. Jakarta: Salemba Infotek.

Surendran dan Nair. 2005. Biochemical characterization of lactic acid bacteria isolated from fish and prawn. Journal of Culture Collections, Vol. 4 : 4852 .

Susilatri. Tanjung, A.R. Pebrina, S. 2010. Faktor-Faktor Yang Mempengaruhi Kinerja Sistem Informasi Akuntansi Pada Bank Umum Pemerintah Kota Pekanbaru. Jurnal Ekonomi, Volume 18, Nomor 2 Juni 2010.

Syafarudin Alwi. 2008. Manajemen Sumber Daya Manusia Strategi Keunggulan Kompetitif. No.008. Yogyakarta.

Tausikal, Askam. 2007. Pengaruh Pemahaman Sistem Akuntansi dan Pengelolaan Keuangan Daerah terhadap Kinerja Satuan Kerja Perangkat Daerah. Jurnal Akuntansi dan Keuangan Sektor Publik, Vol.08, No.01.

Tausikal, Askam. 2009. Pengaruh Pengawasan, Pemahaman Sistem Akuntansi Keuangan Dan Pengelolaan Keuangan Terhadap Kinerja Unit Satuan Kerja Pemerintah Daerah (Studi Pada Provinsi Dan Kabupaten/KotaDi Maluku). Jurnal. Universitas Pattimura.

Tharenou, P., Saks, A., \& Moore, C. 2007. A Review and Critique of Research on Training and Organizational Level Outcomes. Human Resource Management. Review, 77(3): 251-273.

Thong, Y. L. \& Ngeow, W. C. 1998. Gaining access through a calcified pulp chamber: a clinical challenge. International Endodontic Journal : p 31, 367-371.

Tika, Pabundu. 2006. Budaya Organisasi dan Peningkatan Kinerja Perusahaan. Jakarta: Cetakan Pertama, PT Bumi Aksara.

Tjhai, Fung Jen. 2002. Faktor-FaktorYang Mempengaruhi Kinerja Sistem Informasi Akuntansi. Jurnal Bisnis dan Akuntansi, Volume IV No.2.

Tjiptoherijanto, Prijono. 2001. Migrasi, Urbanisasi dan Pasar Kerja di Indonesia. Jakarta: UI Press. 
Urban. 2001. Ecosystem Analysis: Identifying Tools and Methods. UNU/IAS Report May.

Vanlommel, E., dan DeBander, B. 1975. The Organization of EDP Activities and Computer Use. Journal of Bussiness.

Vienda, A. 2013. Knowledge Managementas Bridge of Accounting InformationSystem and Strategic Mangement. Journal of Energy Technologies and Policy, Vol 3.No. 11.

Wahyuni, Sri. 2010. Pengaruh Hubungan Partisipasi Terhadap Kepuasanpemakai Dalam Pengembangan Sistem Informasi Dengandukungan Manajemen Puncak Sebagai Variabel Moderating. Ejournal. Fakultas Ekonomi, Unesa, Kampus Ketintang Surabaya. Tersedia dalam : URL: http://. ejournal unesa.ac.id.

Wakano Nursin, August E. Patrriselanno, Raihana Kaplale. 2013. Hubungan Kompetensi Sumber Daya Mnusia Terhadap Kinerja Karyawan Pada PT. Sumber Daya Wahana (SDW) Di Kecamatan Seram Utara Kabupaten Maluku Tengah. Jurnal Agrilan, Volume 1 No.3 Juni 2013. Universitas Pattimura.

Warisno. 2008."Faktor-Faktor yang Mempengaruhi Kinerja Satuan Kerja Perangkat Daerah (SKPD) di Longkungan Pemerintah Provinsi Jambi" (tesis). Medan: Sekolah Pascasarjana USU.

Widodo, Joko. 2001. Good Governance Telaah Dari Dimensi Akuntabilitas, Kontrol Birokrasi Pada Era Desentralisasi Dan Otonomi Daerah. Insan Cendekia. Surabaya.

Winidyaningrum, Celviana \& Rahmawati. 2010. Pengaruh Sumber Daya Manusia Dan Pemanfaatan Teknologi Informasi Terhadap Keterandalan Dan Ketepatwaktuan Pelaporan Keuangan Pemerintah Daerah Dengan Variabel Intervening Pengendalian Intern Akuntansi (Studi Empiris Di Pemda Subosukawonosraten). Simposium Nasional Akuntansi XIII Purwokerto 2010.

Yunina. 2014. Pengaruh Kapasitas Sumber Daya Manusia, Pengendalian Intern Akuntansi dan Pemanfaatan Teknologi Informasi Terhadap Ketepatan Waktu Pelaporan Keuangan Pemerintah Kabupaten Pidie Jaya. Jurnal.

Yusrawati. 2003. "Pengaruh Partisipasi Pemakai Terhadap Kepuasan Pemakai dalam Pengembangan Sistem Informasi Dengan Lima Faktor Kontijensi Sebagai Variabel Moderating" (tesis). Universitas Diponegoro. 
Sang Ayu Nyoman Trisna Dewi, dan I Dewa Nyoman Badera. Dukungan Manajemen...

www.djkd.kemendagri.go.id. -------. Diakses tanggal 2 bulan Agustus tahun 2013.

www.google.com. http://denpasarkota.go.id/index.php/prestasi. -------. Diakses tanggal 6 bulan Agustus tahun 2016.

http://denpasarkota.go.id/index.php/baca-berita/11165/Web-Pemkot-

Denpasar-Sabet-Dua-Penghargaan-Tingkat-Nasional. 